University of South Carolina

Scholar Commons

1997

\title{
Electrowinning of Nonnoble Metals with Simultaneous Hydrogen Evolution at Flow-Through Porous Electrodes III. Time Effects
}

\author{
Mahmoud M. Saleh \\ University of South Carolina - Columbia \\ John W Weidner \\ University of South Carolina - Columbia, weidner@engr.sc.edu \\ Bahgat E. El-Anadouli \\ Cairo University \\ Badr G. Ateya \\ Cairo University
}

Follow this and additional works at: https://scholarcommons.sc.edu/eche_facpub

Part of the Chemical Engineering Commons

\section{Publication Info}

Journal of the Electrochemical Society, 1997, pages 922-927.

(c) The Electrochemical Society, Inc. 1997. All rights reserved. Except as provided under U.S. copyright law, this work may not be reproduced, resold, distributed, or modified without the express permission of The Electrochemical Society (ECS). The archival version of this work was published in the Journal of the Electrochemical Society. http://www.electrochem.org/

Publisher's link: http://dx.doi.org/10.1149/1.1837508

DOI: $10.1149 / 1.1837508$

This Article is brought to you by the Chemical Engineering, Department of at Scholar Commons. It has been accepted for inclusion in Faculty Publications by an authorized administrator of Scholar Commons. For more information, please contact digres@mailbox.sc.edu. 
Schaefer and M. Keppeler for critically reading the manuscript.

Manuscript submitted March 20, 1996; revised manuscript received Nov. 21, 1996 .

The Max-Planck-Institut für Metallforschung assisted in meeting the publication costs of this article.

\section{REFERENCES}

1. N. Miura, Y. Yan, M. Sato, S. Yao, S. Nonaka, Y. Shimizu, and N. Yamazoe, Sens. Actuators, B24-25,
260 (1995).

2. H. Näfe, ibid., B21, 79 (1994).

3. H. Näfe, Solid State Ionics, 68, 249 (1994)

4. H. Näfe, ibid., 93 (1997).

5. H. Näfe, This Journal, 143, 943 (1996).

6. Thermochemical Properties of Inorganic Substances, $O$. Knacke, O. Kubaschewski, and K. Hesselmann, Editors, Springer-Verlag \& Verlag Stahleisen, Berlin (1991).

7. JANAF Thermochemical Tables, 3rd ed., National Bureau of Standards, Washington, DC (1985).

8. R. Kohli, Thermochim. Acta, 65, 285 (1983).

\title{
Electrowinning of Nonnoble Metals with Simultaneous Hydrogen Evolution at Flow-Through Porous Electrodes
}

\author{
III. Time Effects
}

\author{
Mahmoud M. Saleha and John W. Weidner* \\ Department of Chemical Engineering, University of South Carolina, Columbia, South Carolina, 29208, USA
}

\author{
Bahgat E. El-Anadouli and Badr G. Ateya* \\ Department of Chemistry, Cairo University, Cairo, Egypt
}

\section{ABSTRACT}

The electrowinning of zinc from a recirculating alkaline zincate solution at a flow-through porous electrode was investigated. Experimental results were obtained to test the predictions of a mathematical model. The effects of electrolyte flow rate, cell current, and electrode thickness on the concentration-time relations and coulombic efficiency-time relations were studied. The experimental results show that the highest recovery rate was obtained at both high flow rates and cell currents. There is, however, a practical limit for increasing both the cell current and the electrolyte flow rate. Reasonable agreement between the model predictions and experimental results was obtained. A case study is presented to show how the model equations are used to predict the relationship between time, cell current, flow rate, and coulombs passed which are required to recover $95 \%$ of the zinc content of the electrolyte.

\section{Introduction}

Recently the effects of charge-transfer kinetics and ohmic and mass-transfer resistances on the electrowinning of nonnoble metals at flow-through porous electrodes have been studied. ${ }^{1,2}$ The main advantage of porous over planar electrodes is that they provide a larger ratio of surface area to electrode volume. This leads to smaller cell designs and less electrode material. The scale-up of porous electrodes, however, is more complicated due to the threedimensional structure of the electrode. Mathematical models can aid in the design and operation of porous electrodes in order to maximize the advantage of these high-surfacearea materials. The theory and operation of porous electrodes have been developed to sophisticated levels, including their use in the recovery of relatively noble metals such as copper (see, for example, Ref. 3 and 4). These previous studies of copper removal have demonstrated that large single-pass conversions can be achieved when operated at low flow rates.

Unfortunately, this low flow-rate regime can cause operational problems during the electrowinning of a nonnoble metal due to simultaneous hydrogen evolution. Therefore, a theoretical model was developed to predict the effect of gas bubbles on the coulombic efficiency and current distributions of the metal and the hydrogen evolution reactions under steady-state operating conditions, assuming the electrolyte passes only once through the porous electrode. ${ }^{1}$ The predictions of the model were compared to the experimental results obtained for the electrowinning of zinc from alkaline zincate solutions over a range of flow rates, cell currents, and electrode thicknesses. ${ }^{2}$ The results presented thus far $^{1,2}$ are valid for one pass

* Electrochemical Society Active Member.

a Permanent address: Department of Chemistry, Cairo University, Cairo, Egypt. of electrolyte through the cell. For more efficient recovery, the electrolyte is recirculated until its metal content is substantially reduced. As a result of the gradual decrease of the zincate concentration in the reservoir, the equilibrium potential, exchange current density, and mass-transfer limiting current of the zincate reduction reaction change continuously. In principle, similar changes also occur in the hydrogen evolution reaction if the $\mathrm{pH}$ of the electrolyte changes. A pH change would affect the current and potential distributions, the coulombic efficiency, and polarization behavior of the electrode over time.

The objective of this paper is to analyze the time effects associated with zinc electrowinning within the framework of the mathematical model presented previously. ${ }^{1}$ Because the previous model was developed under steady-state conditions, it must be modified to allow for changes of the concentration-dependent parameters with time. Simulated data of concentration and coulombic efficiency as a function of time are compared to the corresponding experimental results obtained on the electrowinning of zinc from alkaline zincates at different electrolyte flow rates, cell currents, and electrode thicknesses. The electrowinning of zinc in an alkaline electrolyte was chosen as the model system due to the increased interest this system is receiving owing to its lower energy consumption and increased productivity relative to a conventional acidic electrolyte. ${ }^{5-?}$

\section{Experimental}

The flow system and cell arrangement were reported previously. ${ }^{2}$ The porous electrode was made of spherical zinc particles $(0.2 \mathrm{~cm}$ diam) of high purity $(99.99 \%)$. Table I shows the specifications of the electrodes used in the present work. The counterelectrode was made of a platinum screen, and the reference electrodes were $\mathrm{Hg} / \mathrm{HgO} / 1 M \mathrm{KOH}$. Current densities were calculated on the basis of the geometrical cross-sectional area of the 
Table I. Specifications for the porous electrodes."

\begin{tabular}{lcc}
\hline \multicolumn{1}{c}{ Property } & $\begin{array}{c}\text { Zinc } \\
\text { spheres }\end{array}$ & $\begin{array}{c}\text { Galvanized } \\
\text { screens }\end{array}$ \\
\hline Porosity & 0.30 & 0.80 \\
Specific surface area & $14.0 \mathrm{~cm}^{-1}$ & $20.0 \mathrm{~cm}^{-1}$ \\
Particle diameter & $0.20 \mathrm{~cm}$ & $0.05 \mathrm{~cm}$ \\
\hline
\end{tabular}

a The zinc spheres were used in all experiments reported here The galvanized screens were used in a previous paper ${ }^{5}$ and their specifications are used in the case study (see Fig. 7).

electrode. All experiments were performed galvanostatically using an EG\&G potentiostat Model 273A. The electrolyte was recirculated from a $500 \mathrm{ml}$ well-mixed reservoir using a variable speed pump. The flow rate was measured using a calibrated float sphere-type flowmeter. The concentration of zincate was measured by analyzing samples from the electrolyte at various time intervals using an atomic absorption spectrometer. The zincate solutions were prepared by dissolving the desired weights of $\mathrm{ZnO}$ in $3.0 \mathrm{M} \mathrm{KOH}$. Measurements were taken at $25 \pm 1^{\circ} \mathrm{C}$.

\section{Model Development}

The simultaneous reactions involved in the electrowinning of zinc from an alkaline zincate solution are

$$
\begin{aligned}
\mathrm{Zn}(\mathrm{OH})_{4}^{2-}+2 e^{-}=\mathrm{Zn}+4 \mathrm{OH}^{-} & E^{\circ}=-1.216 \mathrm{~V} \text { (SHE) [1] } \\
2 \mathrm{H}_{2} \mathrm{O}+2 e^{-}=\mathrm{H}_{2}+2 \mathrm{OH}^{-} & E^{\circ}=-0.828 \mathrm{~V} \text { (SHE) [2] }
\end{aligned}
$$

Both of these reactions lead to an increase in the alkali concentration in the electrolyte. However, because the $\mathrm{KOH}$ concentration used in this study is much greater than that of zincate, the effect of $\mathrm{pH}$ changes on the kinetics or thermodynamics of these reactions can be neglected. For example, complete electrowinning of zinc at high coulombic efficiencies from $0.015 \mathrm{M} \mathrm{Zn}(\mathrm{OH})_{4}^{2-}$ dissolved in $3.0 M \mathrm{KOH}$ results in a hydroxyl ion concentration increase of approximately $2 \%$.

The detailed derivation of the model equations was reported in Part I of this study. ${ }^{1}$ The governing equations are introduced below.

$$
\frac{d i_{\mathrm{Zn}_{\mathrm{n}}}(x)}{d x}=-j_{\mathrm{Zn}}(x)=\frac{-S i_{0, \mathrm{Zn}_{\mathrm{n}}}\left[1-\exp \left[2 \eta_{\mathrm{Zn}_{\mathrm{n}}}(x) / b\right]\right]}{\exp \left[\beta \eta_{\mathrm{Zn}}(x) / b\right]+\frac{i_{0, \mathrm{Zn}_{\mathrm{n}}}}{i_{\mathrm{L}, \mathrm{Zn}}}}
$$

See the symbols section for a list of variable definitions. For the hydrogen evolution reaction, the relationship between the hydrogen solution current, $i_{\mathrm{H}}(x)$, and the reaction current, $j_{\mathrm{H}}(x)$, is given by

$$
\frac{d i_{\mathrm{H}}(x)}{d x}=-j_{\mathrm{H}}(x)=-S i_{\mathrm{o}, \mathrm{H}} \exp \left[-\alpha \eta_{\mathrm{H}}(x) / b\right]
$$

The overpotential operating on the individual reactions are related through the difference between their equilibrium potentials, i.e.

$$
\eta_{\mathrm{H}}(x)=\eta_{\mathrm{Zn}}(x)+\Delta E
$$

where $\Delta E=E_{\mathrm{Zn}}-E_{\mathrm{H}}$. The total solution current is the algebraic sum of the two individual solution currents, i.e.

$$
i(x)=i_{\mathrm{Zn}}(x)+i_{\mathrm{H}}(x)
$$

Ohm's law governs the variation in the overpotential as the solution current travels through the gas-electrolyte dispersion filling the pore space. Thus

$$
\begin{gathered}
i(x)=\kappa(x) \frac{d \eta_{\mathrm{z}_{\mathrm{n}}}(x)}{d x} \\
\kappa(x)=\kappa^{\circ}[\theta-\epsilon(x)]^{3 / 2}
\end{gathered}
$$

where $\kappa^{\circ}$ is the bulk electrolyte conductivity. The gas void fraction, $\epsilon(x)$, is related to the hydrogen current by ${ }^{1}$

$$
\epsilon(x)=\frac{\theta i_{\mathrm{H}}(x)}{\left(\frac{Q}{\sigma}\right)+i_{\mathrm{H}}(x)}
$$

where $\sigma$ is a factor which converts the hydrogen current to the volume of gas generated. Assuming ideal gas behavior, $\sigma$ is given $b^{8}{ }^{8}$

$$
\sigma=\frac{R T}{2 P F}
$$

where $\sigma$ equals $0.127 \mathrm{~cm}^{3} / \mathrm{C}$ for the hydrogen evolution reaction at standard pressure and temperature.

At the edge of the porous electrode closest to the counterelectrode (i.e., $x=0$ ), Eq. 6 is replaced by the following boundary condition which equates the solution current to the applied cell current

$$
x=0 \quad i=i_{\text {cell }}
$$

At the far edge of the electrode (i.e., $x=L$ ), Eq. 6, and 7 are replaced by the following boundary conditions which indicate that the individual and total solution currents are zero at this point

$$
x=L i_{\mathrm{H}}=0 \quad \frac{d \eta_{\mathrm{Z}_{\mathrm{n}}}(x)}{d x}=0
$$

Equations 3 to 12 control the behavior of the system under steady-state conditions (i.e., with constant values of the parameters). In the present work, the concentration of zincate ions in the reservoir decreases gradually with time. These changes affect the concentration-dependent parameters (i.e., the equilibrium potential, and exchange- and limiting-current densities of the zincate reduction reaction). Assuming that the reservoir volume is large compared to the volume of the porous electrode, the following equation (Eq. 13) relates the rate of decrease of the zincate concentration in the reservoir to the zinc solution current evaluated at $x=0,\left.i_{\mathrm{Zn}}\right|_{x=0}$

$$
\frac{d C_{\mathrm{Zn}}}{d t}=-\left.\frac{A}{2 F V} i_{\mathrm{zn}}\right|_{x=0}
$$

Integration of Eq. 13 yields

$$
C_{\mathrm{Zn}}=C_{\mathrm{Zn}, \mathrm{ref}}-\left.\frac{A}{2 F V} \int_{0}^{t} i_{\mathrm{Zn}}\right|_{x=0}(t) d t
$$

where $C_{\mathrm{Zn}, \text { ref }}$ is the reference (i.e., initial) bulk concentration of zincate. Note that $i_{\mathrm{zn}} l_{x=0}$ depends on the zincate concentration, and the thermodynamic, kinetic, and masstransfer properties of the porous electrode. Therefore, the time variation of the zincate concentration was obtained by coupling Eq. 14 with Eq. 3 to 12 . These coupled differential equations were solved using explicit time stepping with accuracy of $\mathrm{O}(\Delta t)$ and a finite difference algorithm given by Newman ${ }^{9}$ with accuracy of $\mathrm{O}(\Delta x)^{2}$.

For the zinc reduction reaction, the local limiting current density, the exchange current density, and the equilibrium potential change during the experiment. The relationship between these parameters and the zincate concentration is given by

$$
\begin{gathered}
i_{\mathrm{L}, \mathrm{Zn}}=n F k_{\mathrm{m}} C_{\mathrm{Zn}} \\
i_{\mathrm{o}, \mathrm{Zn}}=i_{\mathrm{o}, \mathrm{Zn}, \mathrm{ref}}\left(\frac{C_{\mathrm{Zn}_{\mathrm{n}}}}{C_{\mathrm{Zn}, \text { ref }}}\right)
\end{gathered}
$$

$E_{\mathrm{Zn}}=-1.315-0.0473 \log M[\mathrm{KOH}]$

$$
+0.0277 \log M\left[\mathrm{~K}_{2} \mathrm{Zn}(\mathrm{OH})_{4}\right]
$$

The equilibrium potential for the hydrogen reaction is assumed constant throughout the experiment and related to the $\mathrm{KOH}$ concentration by the following expression 


$$
E_{\mathrm{H}}=-0.828-0.0591 \log M[\mathrm{KOH}]
$$

Equations 17 and 18 apply at room temperature, and the constants in Eq. 17 were obtained from Ref. 10. The symbols $M[\mathrm{KOH}]$ and $M\left[\mathrm{~K}_{2} \mathrm{Zn}(\mathrm{OH})_{4}\right]$ are the molarities of hydroxide and zincate, respectively.

The local mass-transfer coefficient, $k_{\mathrm{m}}$, is given by the following empirical correlation ${ }^{11}$

$$
k_{\mathrm{m}}=1.17 Q^{0.58}\left(\frac{v}{d}\right)^{0.42}\left(\frac{D}{v}\right)^{0.67}
$$

The physical parameters used in the model are: $i_{0, \mathrm{Zn}, \mathrm{ref}}=$ $6.3 \times 10^{-2} \mathrm{~A} \mathrm{~cm}^{-2} ;{ }^{12} i_{\mathrm{o}, \mathrm{H}}=5.0 \times 10^{-9} \mathrm{~A} \mathrm{~cm}^{-2} ;{ }^{2} \mathrm{D}=1.6 \times$ $10^{-6} \mathrm{~cm}^{2} \mathrm{~s}^{-1} ;{ }^{13} \nu=0.015 \mathrm{~cm}^{2} / \mathrm{s} ;{ }^{14} \kappa^{0}=0.04 \Omega^{-1} \mathrm{~cm}^{-1} ;{ }^{15} \alpha=$ $0.5 ;{ }^{16}$ and $\beta=1.0{ }^{12}$

\section{Results and Discussion}

Effect of electrolyte flow rate.-Figure 1 shows the effect of the electrolyte flow rate on the concentration-time relations using a porous electrode of zinc spheres (see Table I for its parameters). The experimental (symbols) and simulated (solid lines) results were obtained with a cell current of $0.1 \mathrm{~A} \mathrm{~cm}^{-2}$. The figure shows reasonable agreement with the measured results throughout the run for all flow rates. As the flow rate increases from 0.1 to $0.5 \mathrm{~cm} \mathrm{~s}^{-1}$, the recovery rate increases. The recovery rate is the slope of the concentration-time curve. However, upon further increase to $4.5 \mathrm{~cm} \mathrm{~s}^{-1}$, we observe no significant change in the recovery rate for the first $60 \mathrm{~min}$. At longer times $(t>60 \mathrm{~min}$ ), the recovery rate becomes more sensitive to the electrolyte flow rate.

The results in Fig. 1 were further analyzed by obtaining the total zincate limiting current supported by the electrolyte as a function of time. This is given by $i_{\mathrm{L}} S L$, where $i_{\mathrm{L}}$ is the local zincate limiting current given by Eq. 15. The concentrations used to calculate the total limiting current at various times were taken from the experimental data of Fig. 1. Figure 2 shows the variation of the total limiting current with time at different flow rates. The figure reveals the strong effect of flow rate on the total limiting current. The rate of decrease of the limiting current with time depends strongly on the flow rate up to about

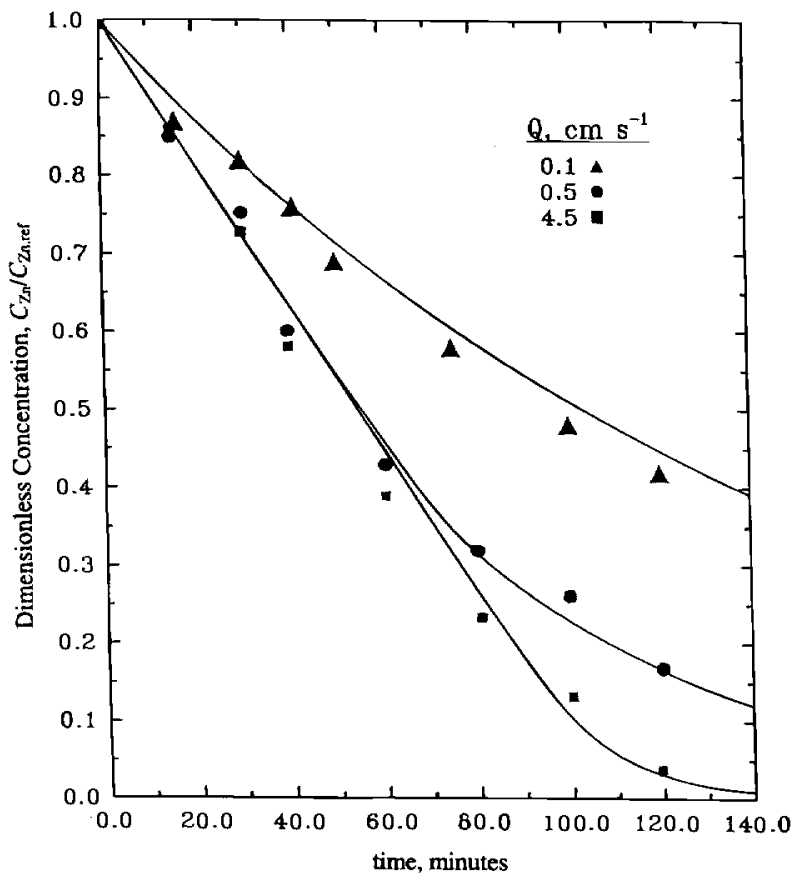

Fig. 1. Concentration-time relations for zinc recovery at different electrolyte flow rates. Solid lines are the model predictions and the symbols are the experimental data. $\left[C_{\mathrm{zn}, \text { ret }}=0.015 \mathrm{M} \mathrm{ZnO;} i_{\text {cell }}=\right.$ $0.1 \mathrm{~A} \mathrm{~cm}^{-2} ; L=2.1 \mathrm{~cm}$.)

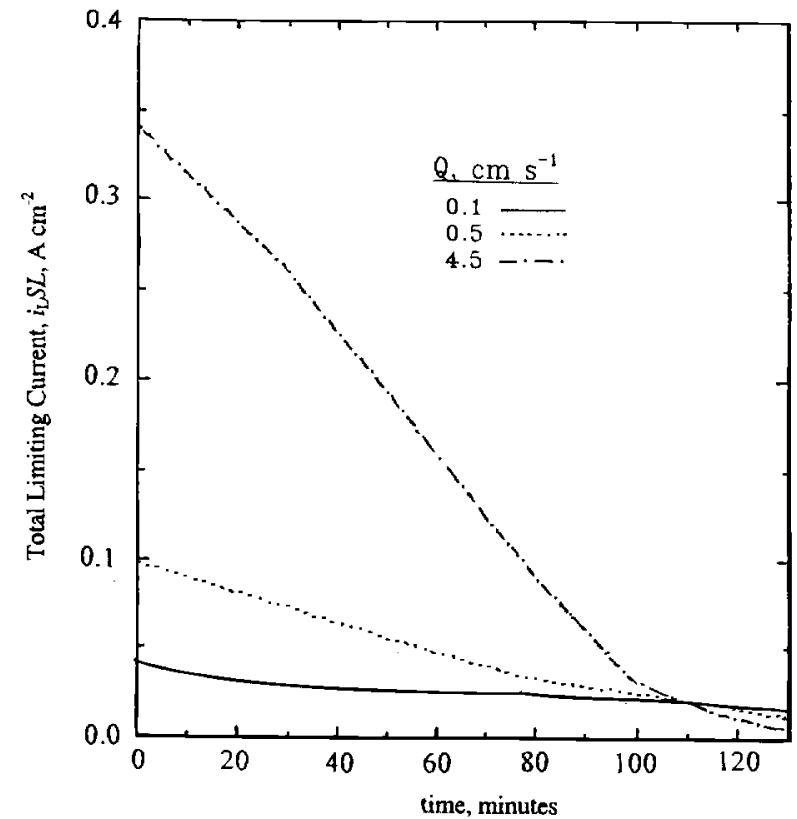

Fig. 2. Total limiting current-time relations for zinc recovery at different electrolyte flow rates. $\left(C_{\mathrm{Zn}_{\text {,ref }}}=0.015 \mathrm{M} \mathrm{ZnO} ; i_{\text {cell }}=0.1 \mathrm{~A}\right.$ $\mathrm{cm}^{-2} ; L=2.1 \mathrm{~cm}$.)

$100 \mathrm{~min}$. At the lowest flow rate $\left(Q=0.1 \mathrm{~cm} \mathrm{~s}^{-1}\right)$, the total limiting current decreases very slowly with time. The results of Fig. 2 reflect the faster depletion rates of zincate ions at the higher electrolyte flow rates seen in Fig. 1. Figure 2 also helps explain why the current-time relationship given in Fig. 1 for $Q=0.5$ and $4.5 \mathrm{~cm} \mathrm{~s}^{-1}$ are almost identical early in the run. The cell current of $0.1 \mathrm{~A} \mathrm{~cm}^{-2}$ is below the limiting current for $Q=4.5 \mathrm{~cm} \mathrm{~s}^{-1}$ and near the limiting current for $Q=0.5 \mathrm{~cm} \mathrm{~s}^{-1}$. Therefore, almost all the current goes into zinc reduction, making the removal rate for the two flow rates nearly equal. Only when the limiting current for $Q=0.5 \mathrm{~cm} \mathrm{~s}^{-1}$ drops significantly below the cell current does the removal rate at $0.5 \mathrm{~cm} \mathrm{~s}^{-1}$ start to lag behind that of the higher flow rate $\left(4.5 \mathrm{~cm} \mathrm{~s}^{-1}\right)$.

The effect of limiting current on the concentration-time curves is further investigated by analyzing the effect of flow rate on the coulombic efficiency-time relations over the duration of an experiment. These results are shown in Fig. 3. Values of the experimental coulombic efficiency were determined by taking the concentration difference between two successive time intervals to obtain $d C_{\mathrm{Zn}} / d t$, using Eq. 13 to obtain $i_{\mathrm{zn}} \mathrm{I}_{x=0}$, and using the following relationship to get the total coulombic efficiency, $\xi$

$$
\xi=\frac{\left.i_{\mathrm{zn}}\right|_{x=0}}{i_{\text {cell }}}
$$

The theoretical values of the total coulombic efficiency were obtained by substituting the calculated values of $i_{\mathrm{Zn}} \mathrm{l}_{x=0}$ into Eq. 20 .

Figure 3 shows that the high flow rates of 0.5 and $4.5 \mathrm{~cm}$ $\mathrm{s}^{-1}$ maintain high coulombic efficiencies $(>95 \%)$ up to about 40 and $80 \mathrm{~min}$, respectively. During these times the limiting current is either greater (for $Q=4.5 \mathrm{~cm} \mathrm{~s}^{-1}$ ) or not much lower (for $Q=0.5 \mathrm{~cm} \mathrm{~s}^{-1}$ ) than the cell current. In contrast, the coulombic efficiency supported by the low flow rate $\left(Q=0.1 \mathrm{~cm} \mathrm{~s}^{-1}\right)$ during this period decreases gradually with time from about $70 \%$ at $t=0$ down to about $50 \%$ at $t=70 \mathrm{~min}$. Again, the dependency of the coulombic efficiency-time curves on the flow rate is related to the dependency of the zinc limiting current on the flow rate (see Fig. 2). At $t<80 \mathrm{~min}$, for $Q=4.5 \mathrm{~cm} \mathrm{~s}^{-1}$, the total limiting current is higher than the cell current. At longer times $(t>80 \mathrm{~min})$, the estimated limiting current decreases below the measured cell current. Consequently, 
at $t>80$ min the hydrogen reaction begins to contribute to the measured cell current and hence lower coulombic efficiencies are progressively obtained. At the flow rate of $0.5 \mathrm{~cm} \mathrm{~s}^{-1}$, the coulombic efficiency does not change much with time because of the constancy of the limiting current.

Figure 3 shows also that as the flow rate increases, the coulombic efficiency increases at times $<110 \mathrm{~min}$ but decreases at times $>110 \mathrm{~min}$. This is again related to the observation in Fig. 2 that the limiting current increases with flow rate for times less than $110 \mathrm{~min}$, but decreases with flow rate at times greater than $110 \mathrm{~min}$. The model predictions shown in Fig. 3 (solid lines) show satisfactory agreement with the experimental results (symbols).

Effect of cell current.-Figure 4 shows the effect of the cell current, $i_{\text {cell }}$, on the concentration-time relations at an electrolyte flow rate of $1.0 \mathrm{~cm} \mathrm{~s}^{-1}$. As the cell current increases from 0.1 and $0.2 \mathrm{~A} \mathrm{~cm}^{-2}$, the rate of zinc recovery increases. However, further increase in current to $0.45 \mathrm{~A}$ $\mathrm{cm}^{-2}$ does not increase the recovery rate significantly. It was shown previously ${ }^{1}$ that at low cell currents the coulombic efficiency is close to $100 \%$. Therefore, increasing the cell current increases the zinc current and hence increases the recovery rate. However, as the cell current is increased beyond the total zinc limiting current, increases in cell current go into hydrogen production rather than zinc reduction. This effect explains why the increase in cell current from 0.2 to $0.45 \mathrm{~A} \mathrm{~cm}^{-2}$ has little effect on the recovery rate. Additional information regarding the effect of cell current on recovery rate can be found in the previous work. ${ }^{1,2}$

The results of Fig. 4 were used to calculate the effect of the cell current on the coulombic efficiency-time relations at a flow rate of $1.0 \mathrm{~cm} \mathrm{~s}^{-1}$ (see Fig. 5). Due to mass-transfer limitations, the coulombic efficiency decreases with time in a mode dependent on cell current. Thus for a cell current of $0.1 \mathrm{~A} \mathrm{~cm}^{-2}$, the coulombic efficiency remains close to $95 \%$ for about $160 \mathrm{~min}$. As the cell current increases to $0.2 \mathrm{~A} \mathrm{~cm}^{-2}$, the coulombic efficiency decreases below $95 \%$ after only $40 \mathrm{~min}$ and decays exponentially with time until it reaches approximately $15 \%$ after

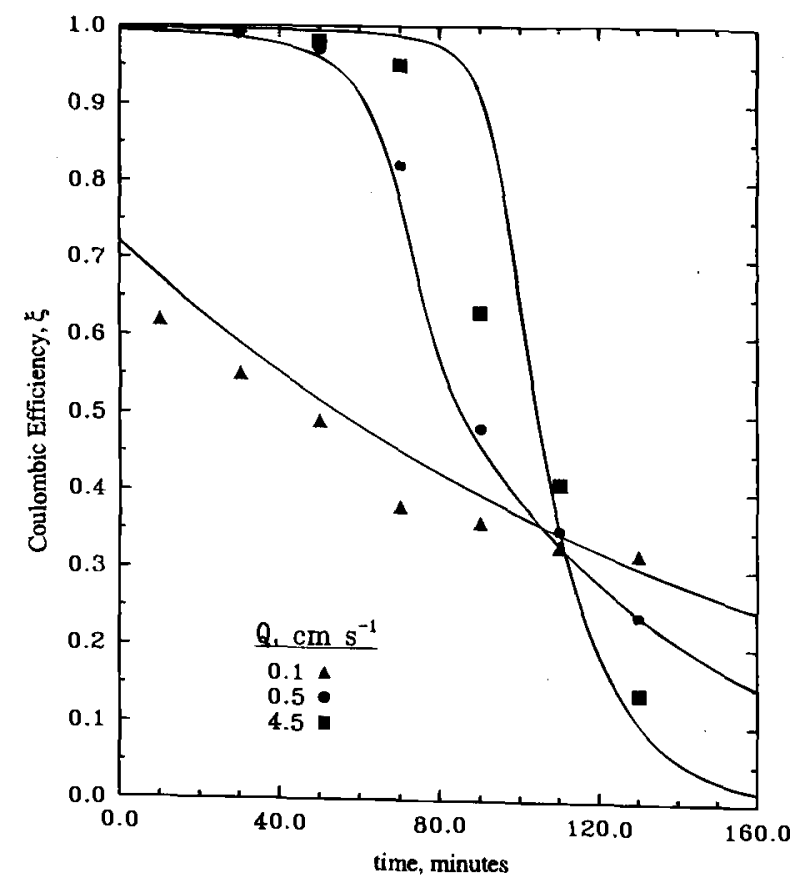

Fig. 3. Coulombic efficiency-time relations for zinc recovery at different electrolyte flow rates. Solid lines are the model predictions and the symbols are the experimental data. $\left(C_{\mathrm{zn}, \text { ref }}=0.015 \mathrm{M} \mathrm{ZnO}\right.$; $i_{\text {cell }}=0.1 \mathrm{~A} \mathrm{~cm}^{-2} ; L=2.1 \mathrm{~cm}$.)

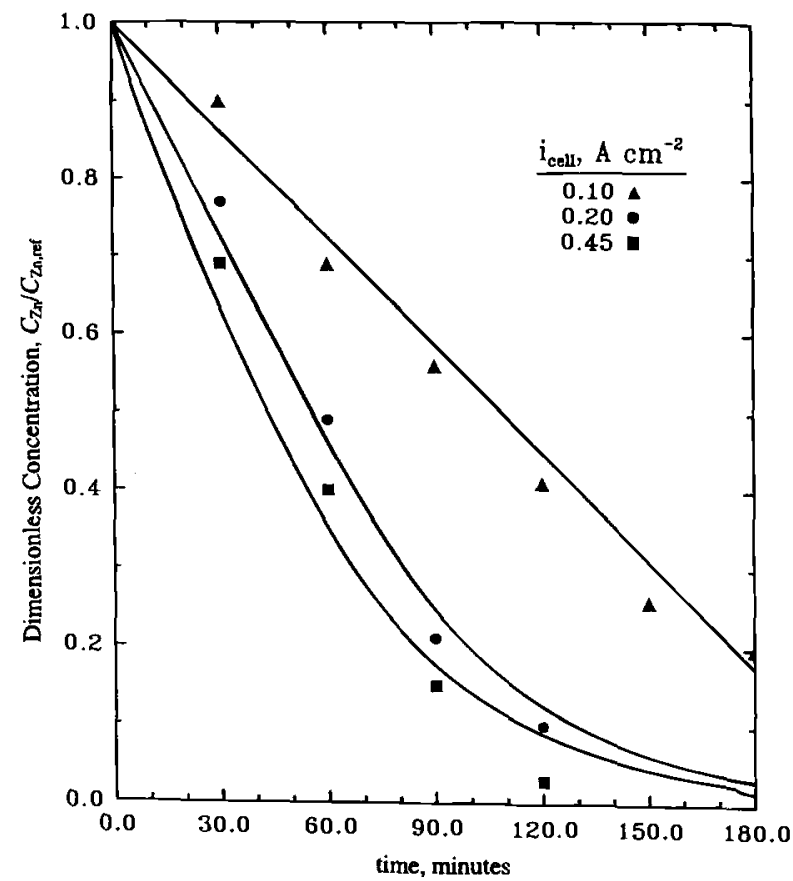

Fig. 4. Concentration-time relations for zinc recovery at different cell currents. Solid lines are the model predictions and the symbols are the experimental data. $\left(C_{\mathrm{zn}, \mathrm{rat}}=0.030 \mathrm{M} \mathrm{ZnO} ; Q=1.0 \mathrm{~cm} \mathrm{~s}^{-1}\right.$; $L=2.1 \mathrm{~cm}$.)

$160 \mathrm{~min}$. At a greater cell current of $0.45 \mathrm{~A} \mathrm{~cm}^{-2}$, the effect is even more pronounced. That is, the coulombic efficiency is $<70 \%$ at the very start of the electrolysis $(t=0)$ and decays exponentially with time, reaching a value of less than $5 \%$ after $160 \mathrm{~min}$.

Effect of electrode thickness.-Figure 6 shows the effect of electrode thickness, $L$, on the concentration-time rela-

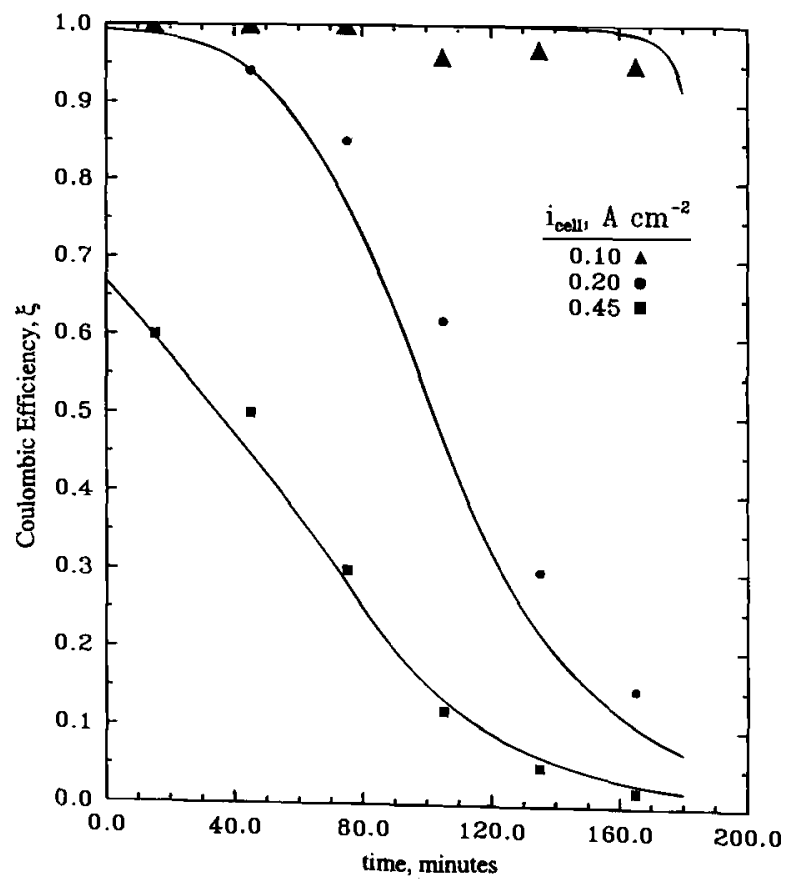

Fig. 5. Coulombic efficiency-time relations for zinc recovery at different cell currents. Solid lines are the model predictions and the symbols are the experimental data. $\left(C_{\mathrm{Zn} \text {,ot }}=0.030 \mathrm{M} \mathrm{ZnO;} Q=\right.$ $1.0 \mathrm{~cm} \mathrm{~s}^{-1} ; L=2.1 \mathrm{~cm}$.) 


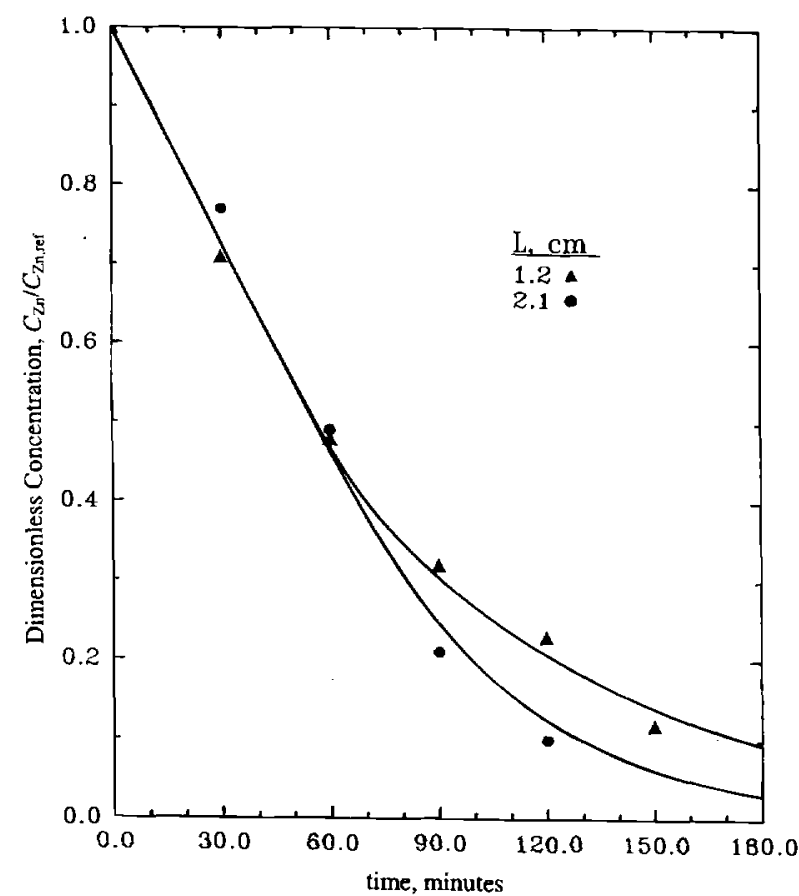

Fig. 6. Concentration-time relations for zinc recovery at different electrode thicknesses. Solid lines are the model predictions and the symbols are the experimental data $\left(C_{\mathrm{zn} \text {,ef }}=0.015 \mathrm{M} \mathrm{ZnO} ; i_{\text {cell }}=\right.$ $0.2 \mathrm{~A} \mathrm{~cm}^{-2} ; Q=1.0 \mathrm{~cm} \mathrm{~s}^{-1}$.)

tions at $Q=1 \mathrm{~cm} \mathrm{~s}^{-1}$ and $i_{\text {cell }}=0.2 \mathrm{~A} \mathrm{~cm}^{-2}$. It is seen that the electrode thickness has no significant effect on the recovery rate over the first $60 \mathrm{~min}$ of operation. According to the model predictions, ${ }^{1,2}$ the current is nonuniformly distributed within the electrode such that the surface area that is supporting the major part of the current is not significantly different between the two cases shown in Fig. 6. At times greater than $60 \mathrm{~min}$, the low zincate concentration in the electrolyte results in a slight increase in recovery rate with electrode thickness.

Case study.-These results reveal that the rate of electrowinning and the coulombic efficiency depend on the electrolyte flow rate, cell current, electrode thickness, zincate concentration, and time. Ideally one wishes to achieve fast electrowinning at a high coulombic efficiency. Higher rates of electrowinning can be attained by using higher cell currents and higher flow rates. However, the use of higher cell currents can be detrimental to the coulombic efficiency, while the maintenance of a high flow rate increases the cost of pumping. There is an interesting optimization problem which can be solved using the input obtained from these equations. In view of this, a case study is presented to show how the model equations are used to predict the relationship between time, cell current, flow rate, and coulombs passed which are required to recover $95 \%$ of the zinc content of a solution of $0.03 \mathrm{M}$ zincate $(\sim 2000 \mathrm{ppm})$ in $3 \mathrm{M} \mathrm{KOH}$.

Figure 7 shows the effects of the cell current and electrolyte flow rate on the time required and the charges passed to recover $95 \%$ of zincate ions. At low cell currents (i.e., below the limiting current for zincate reduction), the recovery time decreases rapidly with current. At large cell currents the recovery time is relatively insensitive to current because the cell is being operated under mass-transfer limitations. Increasing the cell current results only in an increase in the rate of the undesired hydrogen evolution reaction. The recommended operating current, therefore, is a balance between maximizing the current efficiency and minimizing the recovery time. It should be noted that the recommended current may be much less than the total limiting current. Due to nonuniform reaction distributions

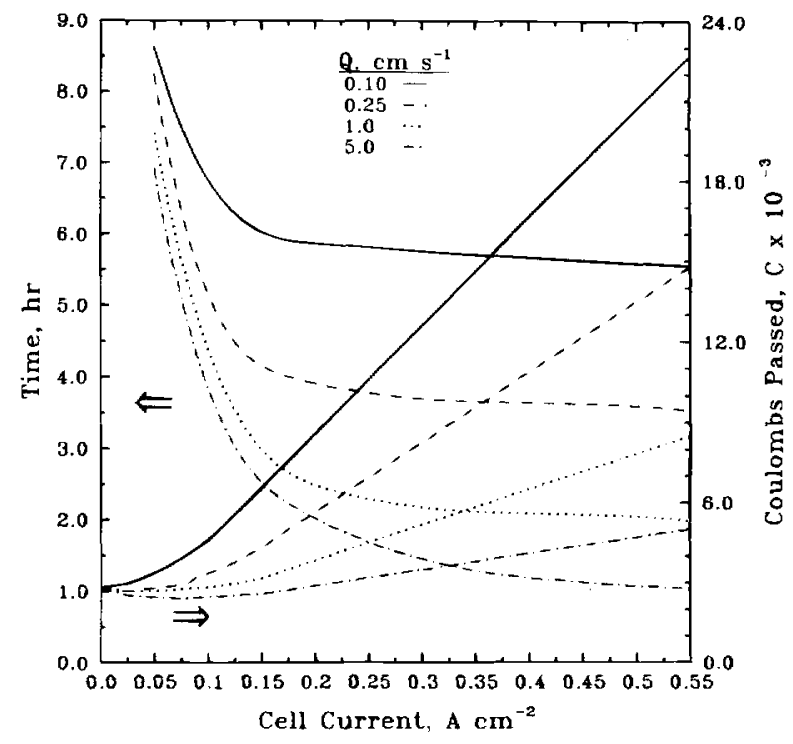

Fig. 7. Time and coulombs passed vs. cell current for $95 \%$ recovery of zinc at different flow rates. All the results were obtained from model calculations using the specifications given for the galvanized screens given in Table $I .\left(C_{\mathrm{zn}, \text { ret }}=0.030 \mathrm{M} \mathrm{ZnO} ; V=500 \mathrm{~cm}^{3}\right.$.)

at high currents, the front of the electrode may be at the local limiting current even though the rest of the electrode is not. The interactions between kinetic, ohmic, and masstransfer resistances that lead to a premature onset in mass-transfer limitations are discussed in detail elsewhere. ${ }^{1}$

From Fig. 7 the recommended operating currents are approximately 0.15 and $0.4 \mathrm{~A} \mathrm{~cm}^{-2}$ at $Q=0.1$ and $0.5 \mathrm{~cm}$ $\mathrm{s}^{-1}$, respectively. The corresponding recovery times are 6.0 and $1.25 \mathrm{~h}$, respectively. As stated previously, increasing the cell current beyond the recommended values obtained from Fig. 7 will not significantly reduce the recovery time for a given flow rate. However, since the limiting current changes during the course of a run (see Fig. 2), a further reduction in recovery time could be achieved by operating at a variable cell current. A high cell current (larger than the one recommend in Fig. 7) could be used early in the process while the concentration and hence the limiting current are high. As time progressed, the cell current could be reduced so as to maintain a high coulombic efficiency. Such a scheme was proposed recently for the efficient reduction of nitrate in a flow-through porous electrode. ${ }^{17}$

Figure 7 reveals two significant features relating to the flow rate. First, at a given cell current the time required to remove $95 \%$ of the zinc decreases as the flow rate increases. This is attributed to an increase in the limiting current and hence an increase in the coulombic efficiency. In other words, the coulombs needed to recover a fixed amount of zinc decrease with an increase in the flow rate. Therefore, as the flow rate increases the recommended cell current requires less time and less coulombs to electrowin the same amount of zinc. The second feature from Fig. 7 is that there is a practical limit for increasing the flow rate. Note that the coulombs passed decrease nonlinearly with the flow rate. For example, as the flow rate increases from 0.1 to $0.25 \mathrm{~cm} \mathrm{~s}^{-1}$ (a factor of 2.5 increase), the time required to achieve $95 \%$ recovery decreases from 6 to $4 \mathrm{~h}$ (a $33 \%$ decrease). However, to achieve a similar reduction in the recovery time of $38 \%$ from 2 to $1.25 \mathrm{~h}$ requires another fivefold increase in the flow rate, from 1.0 to $5.0 \mathrm{~cm} \mathrm{~s}^{-1}$. Because an increase in the flow rate is associated with an increase in pumping costs, the cell current, cell voltage, and flow rate must be examined simultaneously when performing a detailed cost and optimization analysis.

\section{Conclusions}

A mathematical model was developed to predict the concentration-time relations and coulombic efficiency- 
time relations for zincate reduction at flow-through porous electrodes. The bulk concentration was updated to recalculate the physical parameters which change with concentration (i.e., with time). High recovery rates were predicted at both high flow rates and high cell currents. Reasonable agreement between the model predictions and experimental results was obtained. A case study was introduced to illustrate the relationship between time, cell current, flow rate, and coulombs passed which are required to recover $95 \%$ of the zinc content of the electrolyte. The model could be used to perform a detailed cost and optimization analysis by simultaneously examining the cell current, cell voltage, and flow rate for a particular cell design.

\section{Acknowledgment}

The authors thank the Egyptian Cultural and Educational Bureau (Washington, DC) for supporting this work through a scholarship to $M$. S. This work was initiated while B. G. A. held a senior Fulbright Fellowship. He gratefully acknowledges the support of the U.S.-Egyptian Bi-National Fulbright Commission (Cairo, Egypt) and the Council for International Exchange of Scholars (Washington, DC).

Manuscript submitted April 22, 1996; revised manuscript received Nov. 14, 1996.

The Univeristy of South Carolina assisted in meeting the publication costs of this article.

\section{LIST OF SYMBOLS}

A cross-sectional area of the porous electrode, $\mathrm{cm}^{2}$ b $R T / F, \mathrm{~V}$

$\mathrm{C}_{\mathrm{Zn}} \quad$ zincate concentration, $\mathrm{mol} / \mathrm{cm}^{3}$

$d^{\mathrm{zn}}$ diameter of the sphere, $\mathrm{cm}$

$D$ diffusion coefficient of the zincate ion, $\mathrm{cm}^{2} \mathrm{~s}^{-1}$

$E$ equilibrium potential, V

$E^{\text {o }} \quad$ standard potential, V

$\Delta E$ difference in equilibrium potential between zinc and hydrogen reaction, $\mathrm{V}$

$F \quad$ Faraday's constant, $96500 \mathrm{C} \mathrm{eq}^{-1}$

$i$ solution current per cross-sectional area, $\mathrm{A} \mathrm{cm}^{-2}$

$i_{\text {o }} \quad$ exchange current per reaction area, $\mathrm{A} \mathrm{cm}^{-2}$

$i_{\text {cell }}$ applied cell current per cross-sectional area, $\mathrm{A} \mathrm{cm}^{-2}$

$i_{\mathrm{L}, \mathrm{Z}_{\mathrm{n}}}$ local zincate limiting current per reaction area, $\mathrm{A} \mathrm{\textrm {cm } ^ { - 2 }}$

$j$ reaction current per unit volume, $\mathrm{A} \mathrm{cm}^{-3}$

$k_{\mathrm{m}} \quad$ local mass-transfer coefficient, $\mathrm{cm} \mathrm{s}^{-1}$

$L \quad$ electrode thickness, $\mathrm{cm}$

$P$ pressure, atm

$Q \quad$ superficial electrolyte velocity, $\mathrm{cm} \mathrm{s}^{-1}$

$R$ gas constant, $82.06 \mathrm{~cm}^{3} \mathrm{~atm} / \mathrm{mol} \mathrm{K}$

$S$ specific surface area of the porous electrode, $\mathrm{cm}^{-1}$

$t$ time, $\mathrm{s}$
$T$ temperature, $\mathrm{K}$

$V$ volume of the electrolyte, $\mathrm{cm}^{3}$

$x$ distance within the porous electrode, $\mathrm{cm}$

\section{Subscripts}

ref reference (i.e., initial) condition

$\mathrm{H}$ hydrogen

$\mathrm{Zn}$ zincate

$x=0 \quad$ variable evaluated at the edge of the porous electrode closest to the counterelectrode

Greek

$\alpha \quad$ transfer coefficient for the zinc reaction

$\beta$ transfer coefficient for the hydrogen reaction gas void fraction

overpotential

porosity

effective conductivity of the gas-electrolyte dispersion, $\Omega^{-1} \mathrm{~cm}^{-1}$

$\kappa^{\circ} \quad$ conductivity of the bulk electrolyte, $\Omega^{-1} \mathrm{~cm}^{-1}$

$v \quad$ kinematic viscosity, $\mathrm{cm}^{2} \mathrm{~s}^{-1}$

$\xi \quad$ coulombic efficiency of the zinc reaction

$\sigma \quad R T / 2 P F, \mathrm{~cm}^{3} \mathrm{C}^{-1}$

\section{REFERENCES}

1. M. M. Saleh, J. W. Weidner, and B. G. Ateya, This Journal, 142, 4113 (1995)

2. M. M. Saleh, J. W. Weidner, B. E. El-Anadouli, and B. G. Ateya, ibid., 142, 4122 (1995).

3. D. N. Bennion and J. Newman, J. Appl. Electrochem., 2, 113 (1972).

4. A. K. P. Chu, M. Fleischmann, and G. J. Hills, ibid., 4, 323 (1974).

5. J. St-Pierre and D. L. Piron, J. Appl. Electrochem., 16, 447 (1986).

6. D. L. Piron and M. Sider, CIM Bull., 81, 131 (1988).

7. J. St-Pierre and D. L. Piron, J. Appl. Electrochem., 20, 163 (1990).

8. B. G. Ateya and B. E. E. Anadouli, This Journal, 138, 1331 (1991)

9. J. Newman, Electrochemical Systems, p. 552, Appendix C, 2nd ed., Prentice Hall, Englewood Cliffs, NJ (1991).

10. M. G. Isaacson, F. R. McLarnon, and E. J. Cairns, This Journal, 137, 2361 (1990).

11. E. Cussler, Diffusion and Mass Transfer, p. 230, Cambridge University Press, Cambridge, MA (1984).

12. J. O'M. Bockris, Z. Nagy, and A. Domjanovic, This Journal, 119, 285 (1972).

13. D. Naybour, Electrochim. Acta, 13, 763 ( 1968).

14. J. St-Pierre and D. L. Piron, This Journal, 139, 105 (1992).

15. D. Dobos, Electrochemical Data, pp. 242 and 267 , Elsevier Scientific Publishing Company, Amsterdam (1975).

16. S. Lee, This Journal, 118, 1278 (1971).

17. S. Prasad, J. W. Weidner, and A. E. Farell, ibid., 142, 3815 (1995). 